\title{
EFFECTS OF DIETARY ENERGY LEVELS USING CALCIUM SALTS OF FATTY ACIDS ON NUTRITIVE VALUE OF DIETS AND MILK QUALITY IN PERIPARTUM DAIRY GOATS
}

\author{
Efeitos de níveis de energia na dieta utilizando sais de cálcio de ácidos graxos sobre o valor \\ nutritivo das dietas e qualidade do leite em cabras leiteiras no periparto
}

\author{
Rodrigo de Souza ${ }^{1}$, Claudete Regina Alcalde ${ }^{2}$, Bruna Hygino ${ }^{2}$, \\ Bruna Susan de Labio Molina ${ }^{2}$, Geraldo Tadeu dos Santos ${ }^{2}$, Ludmila Couto Gomes ${ }^{2}$
}

\begin{abstract}
Peripartum is a critical period for dairy goats, as dry matter intake (DMI) is not enough to supply the energy requirement for foetal growth and subsequent lactation. The objective of this study was to evaluate the use of calcium salts of fatty acids (CSFA) to increase dietary energy level of peripartum dairy goats and its effects on nutritive value of diets and milk quality. Twenty multiparous Saanen goats (body weight $63.5 \pm 10.3 \mathrm{~kg}$ ) were distributed in a completely randomised design in four treatments at the following dietary energy levels: $2.6 \mathrm{Mcal}$ of metabolisable energy per $\mathrm{kg}$ of dry matter (Mcal ME/kg DM) - control diet; and 2.7, 2.8, and $2.9 \mathrm{Mcal} / \mathrm{kg} \mathrm{DM}$ - with added CSFA. Goats were housed in individual stalls and evaluated in the peripartum period, by measuring body weight (BW), DMI, dry matter and nutrient digestibility of diets, blood composition, and milk quality and yield. Increasing dietary energy level to $2.9 \mathrm{Mcal} \mathrm{ME} / \mathrm{kg}$ DM had no effect on BW and did not limit DMI. CSFA supplementation increased intake of total digestible nutrients and did not affect fibre digestion. Blood triglycerides and cholesterol concentration increased with CSFA addition. The treatments had no effect on milk yield and composition; however, CSFA supplementation changed the fatty acid concentration of milk fat, increasing levels of polyunsaturated and essential fatty acids. In conclusion, peripartum dairy goats supplemented with CSFA to increase dietary energy level up to $2.9 \mathrm{Mcal} \mathrm{ME} / \mathrm{kg} \mathrm{DM}$ had a greater supply of total digestible nutrients and showed altered fatty acid concentration of milk fat.
\end{abstract}

Index terms: Digestibility, calcium soap, fatty acid, Lactoplus ${ }^{\circledR}$, protected fat.

\section{RESUMO}

O periparto é um período crítico para cabras leiteiras, onde a ingestão de matéria seca (IMS) não é suficiente para suprir os requerimentos energéticos para o crescimento fetal e lactação subsequente. Neste estudo, objetivou-se avaliar o uso de sais de cálcio de ácidos graxos (SCAG), para aumentar o nível de energia na dieta de cabras leiteiras no periparto e seus efeitos sobre o valor nutritivo das dietas e qualidade do leite. Vinte cabras multíparas $(63,5 \pm 10,3 \mathrm{~kg})$ foram distribuídas em delineamento inteiramente casualizado, em quatro tratamentos com os seguintes níveis de energia na dieta: 2,6 Mcal de energia metabolizável por kg de matéria seca (EM/kg de MS) - dieta controle; 2,7; 2,8; e 2,9 Mcal de EM/kg de MS - com adição de gordura protegida. As cabras foram confinadas em baias individuais e avaliadas durante o período do periparto, acompanhando o peso corporal (PC), IMS, digestibilidade da matéria seca e dos nutrientes da dieta, concentração bioquímica sanguínea, produção e qualidade do leite. O aumento no nível de energia da dieta até 2,9 Mcal de EM/kg de MS não teve efeito sobre PC e não limitou a IMS. A suplementação com SCAG aumentou a ingestão de nutrientes digestíveis totais, sem afetar a digestão da fibra. As concentrações sanguíneas de colesterol e triglicerídeos aumentaram com a adição de SCAG. Não houve efeito dos tratamentos sobre a produção e composição do leite, entretanto, a suplementação lipídica alterou o perfil dos ácidos graxos da gordura do leite, sendo observados maiores teores de ácidos graxos poli-insaturados e essenciais. Concluindo, cabras leiteiras no periparto, alimentadas com a elevação do nível de energia na dieta para 2,9 Mcal de EM/kg de MS, utilizando a suplementação com SCAG, têm maior suprimento de nutrientes digestíveis totais e alteração na concentração dos ácidos graxos da gordura do leite.

Termos para indexação: Ácidos graxos, digestibilidade, gordura protegida, Lactoplus ${ }^{\circledR}$, sabões de cálcio.

\section{INTRODUCTION}

Peripartum is a critical period for dairy goats, as dry matter intake (DMI) is not enough to supply the energy requirement for foetal growth and subsequent lactation, leading the animals to negative energy balance (NEB), which predisposes them to nutritional disorders and affects productive and reproductive performance (Rodrigues; Rodrigues; Branco, 2007).

Lipid supplementation has been used in dairy diets to increase dietary energy density, reducing body reserve mobilisation during the NEB period. However, the

\footnotetext{
${ }^{1}$ Universidade Estadual de Maringá/UEM-Departamento de Zootecnia-Avenida Colombo-n. 5790-87020-900-Maringá-Paraná-Brasil-rodrizoo@yahoo.com.br 2Universidade Estadual de Maringá/UEM - Departamento de Zootecnia - Maringá - Paraná - Brasil

Received in august 21, 2013 and approved in april 2, 2014
}

Ciênc. Agrotec., Lavras, v.38, n. 3, p.286-294, maio./jun., 2014 
presence of unsaturated fatty acids (FA) in the digestion can inhibit rumen and reticulum motility, depressing feed intake (Silva; Rodrigues; Branco, 2007). In addition, the fermentation of structural carbohydrates might be negatively affected by formation of a lipid film that covers the fibres, limiting the access of ruminal microorganisms. There is also a toxic effect of long-chain and unsaturated FA on protozoa and Gram-positive bacteria, impairing cellulolytic activity (Palmquist; Mattos, 2011).

To minimise the effects of lipid supplementation on ruminal fermentation, protected fat sources can be used, such as calcium salts of fatty acids (CSFA), obtained by reaction of calcium ions with FA. The principle is based on the passage of this complex through the rumen and its dissociation in the acidic conditions of the abomasum, making it available for digestion and absorption (Silva; Rodrigues; Branco, 2007).

Therefore, is possible to supplement safely higher amounts of lipids, which can be a tool to manipulate milk fat yield and composition (Chilliard; Ferlay; Rouel, 2003).

Thus, the objective of this study was to evaluate the use of CSFA to increase dietary energy level of peripartum dairy goats and its effects on nutritive value of diets and milk quality.

\section{MATERIAL AND METHODS}

The control diet had 2.6 Mcal ME/kg dry matter (DM), which was formulated according to the NRC (2007) requirements for Saanen goats with $60 \mathrm{~kg}$ of body weight producing $3.0 \mathrm{~kg}$ daily milk. In the remaining treatments, fat was added in the form of calcium salts of long-chain FA, using a commercial product based on soybean oil (Lactoplus ${ }^{\mathbb{R}}$, Dalquim Chemical Industry Ltd.), to obtain the following energy levels: $2.7 ; 2.8$; and 2.9 Mcal ME/kg DM (Table 1).

The trial period was from 21 days prepartum (preceded by 14 days of adaptation) to 21 postpartum. Animals were housed in individual stalls with ad libitum water and access to a solarium in the morning for 2 hours.

Goats were fed twice daily, at 9:30 am and 2:30 pm. Feed and orts were measured daily. Feed intake was adjusted weekly in order to provide approximately $10 \%$ orts. The milking was done twice daily, at 7:30 am and 3:00 pm, followed by milk weighing.

There were 2 weeks of sampling, at 21 days prepartum and 21 days postpartum. Body weight (BW), dry matter intake (DMI), and nutrient digestibility were measured. The DMI was calculated as the difference between food supplied and the orts during the week of assessment.

To determine DM and nutrient digestibility, faecal samples were collected from the animals' rectum for 6 days in each week of assessment at different times each day $(8,10,12,14,16$, and $18 \mathrm{~h})$, to obtain a combined sample for each animal. The samples were frozen for later analysis with samples of feed supplied and $10 \%$ of the orts obtained during the sampling days.

For analysis, samples were defrosted, dried in a $55^{\circ} \mathrm{C}$ forced-air oven for $72 \mathrm{~h}$, then ground in a knife mill to pass through a 1-mm screen sieve and stored in plastic bottles. Faecal excretion was estimated by using the indigestible neutral detergent fibre (iNDF) as internal marker, according to adapted methodology from Cochran, Adams and Wallace (1986). The iNDF was obtained after $144 \mathrm{~h}$ of incubation in situ (fistulated goats) of provided food, orts, and faeces in the F57 filter (Ankom ${ }^{\circledR}$ Technology Corporation), followed by neutral detergent fibre (NDF) analysis.

Analysis of DM, ash, crude protein (CP), and ether extract (EE) was performed according to methodology described by Silva and Queiroz (2002). The analysis of NDF was performed using methods described by Van Soest et al. (1991), and the values of total carbohydrates (TC) and total digestible nutrients (TDN) were estimated according to the equations described by Sniffen, O'Connor and Van Soest (1992): TC $(\mathrm{g} / \mathrm{kg} \mathrm{DM})=1000-(\mathrm{CP}+\mathrm{EE}$ + ash $)$; and TDN $=\mathrm{dCP}+(2.25 \mathrm{x} \mathrm{dEE})+\mathrm{dTC}$ where $\mathrm{dCP}$ $=$ digestible crude protein, $\mathrm{dEE}=$ digestible ether extract, and $\mathrm{dTC}=$ digestible total carbohydrates. Nonstructural carbohydrate (NSC) values were estimated according to the equation described by Van Soest et al. (1991): NSC $(\mathrm{g} / \mathrm{kg} \mathrm{DM})=1000-(\mathrm{NDF}+\mathrm{CP}+\mathrm{EE}+\mathrm{ash})$.

At 21 days in milk, proportional milk samples were collected monthly from each animal during both milking times. Milk samples were packed in plastic bottles containing Bronopol ${ }^{\circledR}$ (2-bromo-2-nitropropane1,3-diol) and analysed for fat, protein, lactose, and total solids by infrared spectroscopy in the equipment Bentley $2000^{\circledR}$ (Bentley Instrument Inc.). Milk somatic cell count (SCC) was obtained by the flux cytometry method in the equipment Somacount $500^{\circledR}$ (Bentley Instrument Inc.). The equipments used is calibrated for cow milk analysis; however, it can be safely used for analysis of goat milk, according to Arcuri, Silva and Brito (2004) and Andrade, Souza and Penna (2008).

Milk samples were collected for analysis of FA concentration of milk fat, and blood was collected for analysis of biochemical composition. Fat in milk was separated by centrifugation as described by Murphy, Connolly and Mcneill (1995), and FA was methylated according to method 5509 of ISO (1978) using KOH/ methanol and $n$-heptane. FA methyl ester concentrations were measured by a gas chromatography system (GC Ultra Trace, Thermo Scientific) equipped with a flame 
ionisation detector (at $240{ }^{\circ} \mathrm{C}$ ), a fused silica capillary column detector, and a CP-7420 fused silica capillary column ( $100 \mathrm{~m}$ and $0.25 \mathrm{~mm}$ i.d., 0.25 -m film thickness). FA were quantified by comparison with the retention time of FA methyl ester sample standards (Sigma Aldrich ${ }^{\circledR}$ ).

At 21 days in milk, blood samples were collected after milking in the morning (before meals), through jugular vein puncture. The samples were placed in test tubes of 10 $\mathrm{ml}$ volume and then centrifuged at 3,500 rpm for $15 \mathrm{~min}$ to obtain serum. The serum was stored in Eppendorf tubes and analysed by a Vitalab Selectra- $2^{\circledR}$ autoanalyser using Merck diagnostic kits for cholesterol, triglycerides, and glucose.

The effects of dietary energy levels on BW, feed intake, digestibility, milk composition, blood chemistry concentration, and FA concentration of milk fat were evaluated using linear and quadratic regressions with the statistical software SPSS (Version 18). The best fit model was selected based on Tukey test $(\mathrm{P}<0.05)$.

\section{RESULTS AND DISCUSSION}

During the prepartum period, the treatments had no effect $(\mathrm{P}>0.05)$ on DMI and BW (Table 2), which corroborates results of Zambom, Alcalde and Macedo (2006), who evaluated dietary energy levels in Saanen goats during prepartum, and results of Sahlu, Hart and Le-Trong (1995) in Alpine goats.

DMI in prepartum was $18.5 \mathrm{~g} / \mathrm{kg} \mathrm{BW}$, very close to the value observed by Zambom Alcalde and Macedo (2006), $18.3 \mathrm{~g} / \mathrm{kg}$ of BW, which attribute the low intake to the improved growth of the fetus in late gestation and, consequently, reduction in rumen volume, due to compression by the uterus which, according Rodrigues, Rodrigues and Branco (2007), can be aggravated by the occurrence of multiple births, common in goats.

The diets had no effects on intake of OM, CP, and NDF of prepartum goats. The EE intake increased linearly in response to added fat in the diet, while the added fat had the opposite effect on intake of TC and NSC. The decreased intake of NSC and TC resulted from diet balance, since the addition of fat was accompanied by a decrease in the proportion of corn starch. The control diet had the equivalent of twice the amount of corn compared with the diets with greater levels of CSFA.

Table 1 - Ingredients and chemical composition of experimental diets.

\begin{tabular}{lcccc}
\hline \multirow{2}{*}{ Item (g/kg DM) } & \multicolumn{3}{c}{ Diets (Mcal ME/kg DM) } \\
\cline { 2 - 4 } & 2.6 & 2.7 & 2.8 & 2.9 \\
\hline Corn silage & 574.8 & 600.0 & 600.0 & 600.0 \\
Ground corn & 244.4 & 185.7 & 154.1 & 122.6 \\
Soybean meal & 172.6 & 179.5 & 184.9 & 190.2 \\
Lactoplus $^{\circledR 1}$ & - & 28.7 & 54.6 & 80.5 \\
Limestone & 1.2 & - & - & - \\
Dicalcium phosphate $^{\text {Mineral and vitamin supplement }}{ }^{2}$ & - & 1.1 & 1.3 & 1.6 \\
Dry matter $^{3}$ & 7.0 & 5.0 & 5.0 & 5.0 \\
Organic matter $^{\text {Crude protein }}$ & 528.6 & 513.7 & 517.2 & 518.1 \\
Ether extract $^{4}$ & 951.6 & 949.5 & 944.7 & 941.8 \\
Supplemental fat $^{5}$ & 156.9 & 158.8 & 160.6 & 164.4 \\
Neutral detergent fiber & 28.2 & 26.5 & 25.5 & 24.6 \\
Nonstructural carbohydrates $^{\text {Total carbohydrates }}$ & - & 23.6 & 44.8 & 66.0 \\
\hline
\end{tabular}

${ }^{1}$ Calcium salts of fatty acids; ${ }^{2}$ Chemical composition (per kg of product): A vitamin 135,000 UI; D3 vitamin 68,000 UI; E vitamin 450 UI; Ca 240.0 g; P 71.0 g; K 28.2 g; S 20.0 g; Mg 20.0 g; Cu 400.0 mg; Co 30.0 mg; Cr 10.0 mg; Fe 2.500 mg; I 40.0 mg; Mn $1,350.0 \mathrm{mg}$; Se 15,0 mg; Zn 1,700.0 mg; F $710.0 \mathrm{mg}$ (max); Citric acid 2\% (min) solubility of phosphorus $95 \%$ (min) - commercial product; ${ }^{3} \mathrm{~g} / \mathrm{kg}$ organic matter; ${ }^{4} \mathrm{Obtained}$ by analysis results of corn silage, ground corn and soybean meal; ${ }^{5}$ Information from the manufacturer's manual Lactoplus ${ }^{\circledR}$ (Dalquim Chemical Industry Ltd.). 
Table 2 - Body weight (BW), intake and digestibility of dry matter and nutrients in prepartum dairy goats feeding increasing dietary energy levels using calcium salts of fatty acids.

\begin{tabular}{|c|c|c|c|c|c|c|}
\hline \multirow{2}{*}{ Variable } & \multicolumn{4}{|c|}{ Diets (Mcal ME/kg DM) } & \multirow[t]{2}{*}{ Regression equation; $\mathrm{R}^{2}$} & \multirow[t]{2}{*}{$\mathrm{CV}$} \\
\hline & 2.6 & 2.7 & 2.8 & 2.9 & & \\
\hline BW (kg) & 76.44 & 75.68 & 75.46 & 75.50 & $\mathrm{Y}=75.77 ; \mathrm{ns}$ & 13.36 \\
\hline \multicolumn{7}{|c|}{ Intake (kg/day) } \\
\hline $\mathrm{DM}$ & 1.38 & 1.42 & 1.40 & 1.36 & $\mathrm{Y}=1.39 ; \mathrm{ns}$ & 11.91 \\
\hline $\mathrm{DM}^{1}$ & 18.10 & 19.09 & 18.70 & 18.12 & $\mathrm{Y}=18.50 ; \mathrm{ns}$ & 12.73 \\
\hline $\mathrm{OM}$ & 1.32 & 1.35 & 1.33 & 1.28 & $\mathrm{Y}=1.32 ; \mathrm{ns}$ & 11.88 \\
\hline $\mathrm{CP}$ & 0.23 & 0.25 & 0.25 & 0.26 & $\mathrm{Y}=0.25 ; \mathrm{ns}$ & 12.42 \\
\hline $\mathrm{EE}$ & 0.04 & 0.08 & 0.11 & 0.14 & $Y=-0.873+0.351 X ; 0.90$ & 15.55 \\
\hline NDF & 0.46 & 0.47 & 0.46 & 0.41 & $\mathrm{Y}=0.45 ; \mathrm{ns}$ & 12.34 \\
\hline $\mathrm{TC}$ & 1.05 & 1.02 & 0.97 & 0.87 & $Y=2.631-0.601 X ; 0.30$ & 11.63 \\
\hline $\mathrm{NSC}$ & 0.59 & 0.55 & 0.53 & 0.45 & $\mathrm{Y}=1.717-0.432 \mathrm{X} ; 0.43$ & 11.65 \\
\hline TDN & 1.12 & 1.15 & 1.21 & 1.23 & $\mathrm{Y}=1.18 ; \mathrm{ns}$ & 11.80 \\
\hline \multicolumn{7}{|c|}{ Digestibility (kg/kg) } \\
\hline $\mathrm{DM}$ & 0.70 & 0.65 & 0.70 & 0.71 & $\mathrm{Y}=0.69 ; \mathrm{ns}$ & 5.08 \\
\hline $\mathrm{OM}$ & 0.73 & 0.68 & 0.73 & 0.74 & $\mathrm{Y}=0.72 ; \mathrm{ns}$ & 4.38 \\
\hline $\mathrm{CP}$ & 0.71 & 0.72 & 0.75 & 0.79 & $Y=-0.011+0.274 X ; 0.46$ & 4.91 \\
\hline $\mathrm{EE}$ & 0.80 & 0.87 & 0.92 & 0.96 & $Y=-0.580+0.535 X ; 0.90$ & 1.93 \\
\hline NDF & 0.51 & 0.39 & 0.47 & 0.48 & $\mathrm{Y}=0.46 ; \mathrm{ns}$ & 12.10 \\
\hline $\mathrm{TC}$ & 0.73 & 0.65 & 0.71 & 0.68 & $\mathrm{Y}=0.69 ; \mathrm{ns}$ & 4.84 \\
\hline $\mathrm{NSC}$ & 0.89 & 0.88 & 0.92 & 0.87 & $\mathrm{Y}=0.89 ; \mathrm{ns}$ & 4.00 \\
\hline TDN & 0.72 & 0.71 & 0.78 & 0.82 & $Y=-0.291+0.381 X ; 0.61$ & 4.05 \\
\hline
\end{tabular}

${ }^{1} \mathrm{~g} / \mathrm{kg}$ of body weight $\mathrm{ns}=\mathrm{P}>0.05 ; \mathrm{R}^{2}=$ coefficient of determination; $\mathrm{CV}=$ coefficient of variation (\%); $\mathrm{DM}=$ dry matter; OM = organic matter; $\mathrm{CP}=$ crude protein; $\mathrm{EE}=$ ether extract; $\mathrm{NDF}=$ neutral fiber detergent; $\mathrm{TC}=$ total carbohydrates; $\mathrm{NSC}=$ nonstructural carbohydrates; TDN $=$ total digestible nutrients.

The opposite effect on the carbohydrate and EE intakes possibly contributed to the equalisation of treatments in relation to TDN intake, which was not affected by the treatments. Zambom, Alcalde and Macedo (2006) also found that including soybean oil in the diet had no effect on TDN intake in the prepartum period, despite a higher EE intake.

The treatments had no effect on NDF digestibility in prepartum (Table 2), confirming that CSFA did not interfere with fibre digestion. There were also no observed effects of the treatments $(\mathrm{P}>0.05)$ on the digestibility of $\mathrm{DM}, \mathrm{OM}, \mathrm{TC}$, and NSC in prepartum. However, there was a linear increase in digestibility of $\mathrm{CP}$ with the addition of fat in the diet, which may have resulted from a greater deamination of the protein by rumen microorganisms to obtain energy.

As discussed previously, with fat addition there was starch source reduction; however, there was no reduction of protein level in the diets. Consequently, the relationship between protein and the energy available to rumen fermentation has been changed, since rumen microorganisms are unable to use fat as an energy source for their growth (Arcuri; Lopes; Carneiro, 2011).

According to Rapetti and Bava (2008), in situations where energy is limiting there is an increase in deamination 
of amino acids by rumen microorganisms, which then ferment the carbon skeletons to use as an energy source. As the efficiency of the use of ammonia for microbial protein synthesis is dependent on the availability of energy, much of the ammonia formed in the process of deamination is absorbed through the rumen wall, converted to urea in the liver, to then be excreted in the urine and milk, or return to rumen via blood or saliva (Santos; Pedroso, 2011).

Thus, it is possible that the observed increase in $\mathrm{CP}$ digestibility is associated with the decrease in the nitrogen utilisation efficiency for microbial protein synthesis and subsequent amino acid supply for the animals.

In the studies by Sanz Sampelayo, Pérez and Alonso (2002a) and Silva, Rodrigues and Branco (2007), adding protected fat had no effect on CP digestibility in lactating goats. However, unlike the present study, in these studies authors maintained the proportion of rumen fermentable energy and $\mathrm{CP}$ in different diets.

EE digestibility in the prepartum period linearly increased with the addition of protected fat, which was composed of calcium salts of soybean oil, rich in unsaturated FA. Palmquist and Mattos (2011) explain that the unsaturated FA have a higher digestibility than saturated FA due to their property of forming micelles, making them more soluble in the intestine. This facilitates implementation of the water layer associated with the inert intestinal microvilli, increasing absorption of these types of FA. The effects observed in EE and CP digestibility contributed to the linear positive effect on TDN of the increase of fat in the diets (Table 2).

During prepartum and postpartum, BW and DMI were not influenced by fat addition in the diet (Table 3 ), which is in agreement with that observed by Hosam (2011), who supplemented $50 \mathrm{~g}$ of calcium salts/kg DM, and Brown-Crowder, Hart and Cameron (2001), who used partially hydrogenated tallow in diets with up to 81 g EE/kg DM. Rumen decompression in association with energy demand for early lactation increased the DMI by $40 \%$ compared with the prepartum period, reaching 1.95 $\mathrm{kg}$ of DMI (Table 3), which is in agreement with Zambom, Alcalde and Silva (2005b).

In evaluating the nutrient intake during the postpartum period, treatments had an effect only on EE intake, as observed in the prepartum period. However, EE digestibility behaved differently, showing a quadratic effect. Despite unsaturated FA having a greater intestinal absorption capacity (Palmquist; Mattos, 2011), increasing the ingestion level, the maximum EE digestibility ( 0.94 $\mathrm{g} / \mathrm{g}$ ) was achieved at $2.88 \mathrm{Mcal}$ ME. There was no treatment effect on the NDF, NSC, and TC digestibility. CP as well as digestibility of DM, OM, and TDN responded positively linearly with the addition of fat.

Zambom, Alcalde and Martins (2005b) added $46.7 \mathrm{~g}$ soybean oil/kg DM in treatments with dietary energy levels similar to those of the present study during the postpartum period and observed an increase in DM digestibility and nutrients, but this effect was associated with increasing concentrate proportion in diets. Moreover, Silva, Rodrigues and Branco (2007) supplemented goats with calcium salts and observed a reduction in the digestibility of $\mathrm{OM}, \mathrm{CP}$, and $\mathrm{TC}$.

Results observed in peripartum showed that diets with EE levels higher than $90 \mathrm{~g} / \mathrm{kg}$ DM, with using CSFA guaranteed higher nutrient availability, without limiting the DMI, in the period when the DMI is not sufficient to supply energy demands of late gestation and early lactation (Rodrigues, Rodrigues; Branco, 2007).

The values of blood parameters observed at 21 days in milk (Table 4) are within the ranges described as goats reference values by Pugh (2004) for glucose and cholesterol, which has no reference for levels of triglycerides. However, the results confirm the observations in Saanen by Mundim, Costa and Mundim (2007), who evaluated 123 goats and found cholesterol values ranging from $70-175 \mathrm{mg} / \mathrm{dl}$, triglycerides from $6-32 \mathrm{mg} / \mathrm{dl}$, and glucose from $37-69 \mathrm{mg} / \mathrm{dl}$.

There was no treatment effect on the glucose levels, but CSFA supplementation resulted in a linear increase in postpartum levels of cholesterol and triglycerides. During this period, there is intense body reserve mobilisation, particularly fat (Eknæs; Kolstad; Volden, 2006), and lipogenesis suppression in adipocytes (Palmquist; Mattos, 2011) which, in association with lipid supplementation, resulted in increased circulating levels of triglycerides. The increase in cholesterol levels is associated with the demand for biosynthesis of lipoprotein lipid carriers, stimulating intestinal cholesterol biosynthesis and leading to higher serum levels (Nestel; Poyser; Hood 1978).

Milk yield $(3.93 \pm 0.71 \mathrm{~kg})$ and compositions of fat $(43.30 \pm 6.10 \mathrm{~g} / \mathrm{kg})$, lactose $(43.90 \pm 2.20 \mathrm{~g} / \mathrm{kg})$, and protein $(29.92 \pm 3.38 \mathrm{~g} / \mathrm{kg})$ were not affected by diets, which is in agreement with Zambom, Alcalde and Martins (2005a). Eknæs, Kolstad and Volden (2006) explain that, during the NEB, milk yield is maintained by the mobilisation of body reserves, particularly fat. The treatments had no effect on SCC, with an average of $1300.30 \times 10^{3}$ cells $/ \mathrm{ml}$ and a range of $102 \times 10^{3}$ cells $/ \mathrm{ml}$ to $4758 \times 10^{3}$ cells $/ \mathrm{ml}$.

The lipid supplement altered fatty acid concentration of milk fat (Table 5), increasing the incorporation of longchain fatty acids (LCFA) and decreasing the synthesis 
of medium-chain fatty acids (MCFA) in milk. Chilliard, Ferlay and Rouel (2003) have found that a decrease in the content of MCFA can improve the taste of milk. Lipid supplementation decreased levels of lauric FA (12:0) and myristic FA (14:0), which is interesting from the viewpoint of human nutrition, since they cause an increase in plasma levels of low density lipoproteins (LDL), a kind of cholesterol associated with heart disease (Lima; Menezes; Tavares, 2000).
Supplementation improved milk yield and the milk had higher levels of essential FA omega-3 (n3) and omega-6 (n6). There was an increase in polyunsaturated FA, with the minimum level at $2.67 \mathrm{Mcal}$ of ME. The results are in agreement with those observed by Sanz Sampelayo, Pérez and Alonso (2002b) with protected fat diets and Maia, Branco and Mouro (2006) with supplementation of vegetable oils rich in polyunsaturated fat such as soybean oil (from which calcium salts of Lactoplus ${ }^{\circledR}$ are produced).

Table 3 - Body weight (BW), intake and digestibility of dry matter and nutrients in postpartum dairy goats feeding increasing dietary energy levels using calcium salts of fatty acids.

\begin{tabular}{|c|c|c|c|c|c|c|}
\hline \multirow{2}{*}{ Variable } & \multicolumn{4}{|c|}{ Diets (Mcal ME/kg DM) } & \multirow[t]{2}{*}{ Regression equation; $\mathrm{R}^{2}$} & \multirow[t]{2}{*}{$\mathrm{CV}$} \\
\hline & 2.6 & 2.7 & 2.8 & 2.9 & & \\
\hline BW (kg) & 62.50 & 63.02 & 64.00 & 63.72 & $\mathrm{Y}=63.31 ; \mathrm{ns}$ & 16.62 \\
\hline \multicolumn{7}{|c|}{ Intake (kg/day) } \\
\hline $\mathrm{DM}$ & 1.98 & 1.99 & 1.80 & 2.03 & $\mathrm{Y}=1.95 ; \mathrm{ns}$ & 16.09 \\
\hline $\mathrm{DM}^{1}$ & 32.20 & 32.30 & 28.04 & 31.76 & $\mathrm{Y}=31.07 ; \mathrm{ns}$ & 14.22 \\
\hline $\mathrm{OM}$ & 1.89 & 1.89 & 1.70 & 1.91 & $\mathrm{Y}=1.85 ; \mathrm{ns}$ & 16.05 \\
\hline $\mathrm{CP}$ & 0.34 & 0.35 & 0.32 & 0.38 & $\mathrm{Y}=0.35 ; \mathrm{ns}$ & 16.02 \\
\hline $\mathrm{EE}$ & 0.05 & 0.09 & 0.13 & 0.19 & $Y=-1.239+0.493 X ; 0.85$ & 20.13 \\
\hline NDF & 0.64 & 0.67 & 0.58 & 0.64 & $\mathrm{Y}=0.63 ; \mathrm{ns}$ & 16.59 \\
\hline $\mathrm{TC}$ & 1.50 & 1.45 & 1.25 & 1.34 & $\mathrm{Y}=1.38 ; \mathrm{ns}$ & 15.95 \\
\hline NSC & 0.86 & 0.78 & 0.68 & 0.70 & $\mathrm{Y}=0.75 ; \mathrm{ns}$ & 15.65 \\
\hline TDN & 1.39 & 1.37 & 1.42 & 1.64 & $\mathrm{Y}=1.46 ; \mathrm{ns}$ & 17.50 \\
\hline \multicolumn{7}{|c|}{ Digestibility $(\mathrm{kg} / \mathrm{kg})$} \\
\hline $\mathrm{DM}$ & 0.69 & 0.66 & 0.73 & 0.72 & $\mathrm{Y}=0.299+0.146 \mathrm{X} ; 0.21$ & 3.42 \\
\hline $\mathrm{OM}$ & 0.71 & 0.67 & 0.75 & 0.74 & $\mathrm{Y}=0.282+0.158 \mathrm{X} ; 0.24$ & 3.33 \\
\hline $\mathrm{CP}$ & 0.70 & 0.70 & 0.77 & 0.78 & $\mathrm{Y}=-0.117+0.311 \mathrm{X} ; 0.59$ & 3.49 \\
\hline $\mathrm{EE}$ & 0.82 & 0.89 & 0.94 & 0.94 & $Y=-12.698+9.485 X-1.698 X^{2} ; 0.84$ & 2.63 \\
\hline $\mathrm{NDF}$ & 0.44 & 0.38 & 0.48 & 0.48 & $\mathrm{Y}=0.45 ; \mathrm{ns}$ & 10.48 \\
\hline $\mathrm{TC}$ & 0.71 & 0.65 & 0.72 & 0.69 & $\mathrm{Y}=0.69 ; \mathrm{ns}$ & 4.16 \\
\hline NSC & 0.90 & 0.89 & 0.92 & 0.89 & $\mathrm{Y}=0.90 ; \mathrm{ns}$ & 3.30 \\
\hline TDN & 0.70 & 0.69 & 0.79 & 0.81 & $Y=-0.376+0.408 X ; 0.70$ & 3.07 \\
\hline
\end{tabular}


Table 4 - Blood chemistry concentration in postpartum dairy goats feeding increasing dietary energy levels using calcium salts of fatty acids.

\begin{tabular}{lccrrccc}
\hline \multirow{2}{*}{ Variable $(\mathrm{mg} / \mathrm{dl})$} & \multicolumn{4}{c}{ Diets (Mcal ME/kg DM) } & Regression equation; $\mathrm{R}^{2}$ & CV \\
\cline { 2 - 4 } & 2.6 & 2.7 & \multicolumn{1}{c}{2.8} & \multicolumn{1}{c}{2.9} & & \\
\hline Cholesterol & 79.80 & 97.80 & 101.20 & 119.80 & & $\mathrm{Y}=-239.70+123.40 \mathrm{X} ; 0.40$ & 18.64 \\
Triglycerides & 14.20 & 17.20 & 21.40 & 21.00 & $\mathrm{Y}=-49.20+24.60 \mathrm{X} ; 0.23$ & 29.96 \\
Glucose & 57.00 & 51.00 & 54.80 & 54.80 & & $\mathrm{Y}=54.40 ; \mathrm{ns}$ & 10.54 \\
\hline
\end{tabular}

$\mathrm{ns}=\mathrm{P}>0.05 ; \mathrm{R}^{2}=$ coefficient of determination; $\mathrm{CV}=$ coefficient of variation $(\%)$.

Table 5 - Fatty acid concentration ( $\mathrm{g} / 100 \mathrm{~g}$ of fatty acids) of fat milk at 21 days in milk of dairy goats feeding increasing dietary energy levels using calcium salts of fatty acids.

\begin{tabular}{|c|c|c|c|c|c|c|}
\hline \multirow{2}{*}{ Variable } & \multicolumn{4}{|c|}{ Diets (Mcal ME/kg DM) } & \multirow{2}{*}{ Regression equation; $\mathrm{R}^{2}$} & \multirow{2}{*}{$\mathrm{CV}$} \\
\hline & 2.6 & 2.7 & 2.8 & 2.9 & & \\
\hline $4: 0$ & 3.57 & 2.66 & 2.79 & 1.23 & $\mathrm{Y}=2.63 ; \mathrm{ns}$ & 80.71 \\
\hline $6: 0$ & 0.62 & 0.50 & 0.56 & 0.49 & $\mathrm{Y}=0.55 ; \mathrm{ns}$ & 54.62 \\
\hline $8: 0$ & 1.28 & 0.93 & 0.93 & 0.73 & $\mathrm{Y}=0.98 ; \mathrm{ns}$ & 46.08 \\
\hline 10:0 & 6.27 & 4.64 & 4.37 & 3.14 & $Y=31.13-9.64 X ; 0.30$ & 37.43 \\
\hline $12: 0$ & 3.04 & 2.18 & 2.10 & 2.05 & $Y=165.67-115.94 X+20.53 X^{2} ; 0.32$ & 27.65 \\
\hline $13: 0$ & 0.08 & 0.02 & 0.03 & 0.03 & $\mathrm{Y}=0.04 ; \mathrm{ns}$ & 80.47 \\
\hline $14: 0$ & 8.99 & 7.41 & 7.06 & 6.69 & $Y=27.94-7.42 X ; 0.34$ & 16.21 \\
\hline $15: 0$ & 0.65 & 0.46 & 0.33 & 0.16 & $\mathrm{Y}=4.84-1.61 \mathrm{X} ; 0.42$ & 58.28 \\
\hline $16: 0$ & 27.54 & 27.96 & 28.03 & 27.86 & $\mathrm{Y}=27.85 ; \mathrm{ns}$ & 4.86 \\
\hline 18:0 & 15.61 & 19.10 & 17.94 & 16.84 & $\mathrm{Y}=17.40 ; \mathrm{ns}$ & 21.59 \\
\hline $18: \ln 9 t$ & 1.41 & 3.42 & 4.92 & 6.04 & $Y=-38.77+15.54 X ; 0.43$ & 60.14 \\
\hline $18: \ln 9 \mathrm{c}$ & 25.58 & 25.16 & 25.38 & 25.76 & $\mathrm{Y}=25.45 ; \mathrm{ns}$ & 19.42 \\
\hline $18: 2 \mathrm{n} 6 \mathrm{c}$ & 2.44 & 2.77 & 2.96 & 5.62 & $Y=410.57-306.26 X+57.44 X^{2} ; 0.71$ & 23.54 \\
\hline $18: 3 n 6$ & 0.01 & 0.01 & 0.02 & 0.02 & $\mathrm{Y}=0.02 ; \mathrm{ns}$ & 89.14 \\
\hline $18: 3 n 3$ & 0.13 & 0.15 & 0.14 & 0.33 & $Y=28.49-21.20 X+3.96 X^{2} ; 0.55$ & 39.03 \\
\hline $20: 1$ & 0.21 & 0.35 & 0.34 & 0.39 & $\mathrm{Y}=0.32 ; \mathrm{ns}$ & 70.11 \\
\hline Others ${ }^{1}$ & 2.57 & 2.28 & 2.10 & 2.62 & $\mathrm{Y}=2.39$ & - \\
\hline SCFA & 5.47 & 4.08 & 4.28 & 2.45 & $\mathrm{Y}=4.16 ; \mathrm{ns}$ & 54.70 \\
\hline MCFA & 19.24 & 15.04 & 14.28 & 12.58 & $Y=73.14-21.05 X ; 0.34$ & 22.80 \\
\hline LCFA & 75.29 & 80.88 & 81.44 & 84.98 & $Y=-1.04+29.71 X ; 0.33$ & 6.29 \\
\hline SFA & 68.87 & 66.92 & 65.31 & 60.33 & $Y=138.52-26.58 X ; 0.28$ & 7.68 \\
\hline MUFA & 28.32 & 29.92 & 31.42 & 33.46 & $\mathrm{Y}=30.64 ; \mathrm{ns}$ & 14.40 \\
\hline PUFA & 2.80 & 3.16 & 3.27 & 6.21 & $Y=456.01-339.64 X+63.61 X^{2} ; 0.68$ & 24.30 \\
\hline n3 & 0.14 & 0.16 & 0.15 & 0.34 & $\mathrm{Y}=30.50-22.65 \mathrm{X}+4.22 \mathrm{X}^{2} ; 0.56$ & 37.12 \\
\hline n6 & 2.64 & 2.99 & 3.11 & 5.82 & $Y=418.35-311.69 X+58.41 X^{2} ; 0.68$ & 23.69 \\
\hline $\mathrm{n} 6: \mathrm{n} 3$ & 18.89 & 21.31 & 22.35 & 17.68 & $\mathrm{Y}=20.18 ; \mathrm{ns}$ & 29.89 \\
\hline
\end{tabular}

${ }^{1}$ others fatty acids; $\mathrm{ns}=\mathrm{P}>0.05 ; \mathrm{R} 2=$ coefficient of determination; $\mathrm{CV}=$ coefficient of variation (\%); $\mathrm{SCFA}=$ short-chain fatty acids (C4:0+C6:0+C8:0); MCFA = medium-chain fatty acids (C10:0 a C15:1); LCFA = long-chain fatty acids (up to C16:0); SFA $=$ saturated fatty acid; MUFA = monounsaturated fatty acids; PUFA = polyunsaturated fatty acid; $\mathrm{n} 3=$ omega-3 fatty acids; $\mathrm{n} 6=$ omega-6 fatty acids. 


\section{CONCLUSIONS}

Increasing dietary energy level to $2.9 \mathrm{Mcal} / \mathrm{kg}$ dry matter, using calcium salts of fatty acids, has no effect on body weight and does not limit dry matter intake in peripartum dairy goats, allowing a larger input of total digestible nutrients and enhancing milk yield. In addition, calcium salts of fatty acids supplementation increases beneficial properties of the milk for human health.

\section{REFERENCES}

ANDRADE, P.V.D.; SOUZA, M.R.; PENNA, C.F.A.M. Características microbiológicas e físico-químicas do leite de cabra submetido à pasteurização lenta pósenvase e ao congelamento. Ciência Rural. 38(5):14241430, 2008.

ARCURI, E.F.; SILVA, P.D.L.; BRITO, J.R.F. Emprego do Somacount 300 , calibrado com leite de vaca, na contagem de células somáticas no leite de cabra.

Ciência Rural. 34(5):1497-1500, 2004.

ARCURI, P.B.; LOPES, F.C.F.; CARNEIRO, J.C.C. Microbiologia do rúmen. In: BERCHIELLI, T.T.; PIRES, A.V.; OLIVEIRA, S.G. et al. Nutrição de

Ruminantes. 2.ed. Jaboticabal: Funep, 2011. p.115-160.

BROWN-CROWDER, I.E.; HART, S.P.; CAMERON, M. Effects of dietary tallow level on performance of Alpine does in early lactation. Small Ruminant Research. 39(3):233-241, 2001.

CHILLIARD, Y.; FERLAY, A.; ROUEL, J. A review of nutritional and physiological factors affecting goat milk lipid synthesis and lipolysis. Journal of Dairy Science. 86(5):1751-1770, 2003.

COCHRAN, R.C.; ADAMS, D.C.; WALLACE, J.D. Predicting digestibility of different diets with internal markers: Evaluation of four potential markers. Journal of Animal Science. 63(5):1476-1483, 1986.

EKNÆS, M.; KOLSTAD, K.; VOLDEN, H. Changes in body reserves and milk quality throughout lactation in dairy goats. Small Ruminant Research. 63(1-2):1-11, 2006.

HOSAM, T. Effects of varying levels of protected fat on performance of Shami goats during early and mid lactation. Turkish Journal of Veterinary and Animal Sciences. 35(2):67-74, 2011.
INTERNATIONAL ORGANIZATION FOR STANDARDIZATION- ISO. Animal and Vegetable Fats and Oils - Preparation of Methyl Esters of Fatty Acids. Geneva: Method ISO 5509, 1978. 24p.

LIMA, F.E.L.; MENEZES, T.N.; TAVARES, M.P. et al. Ácidos graxos e doenças cardiovasculares: uma revisão. Revista de Nutrição. 13(2):73-80, 2000.

MAIA, F.J.; BRANCO, A.F.; MOURO, G.F. Inclusão de fontes de óleo na dieta de cabras em lactação: produção, composição e perfil dos ácidos graxos do leite. Revista Brasileira de Zootecnia. 35(4):15041513, 2006.

MUNDIM, A.V.; COSTA, A.S.; MUNDIM, S.A.P. Influência da ordem e estádios da lactação no perfil bioquímico sangüíneo de cabras da raça Saanen. Arquivo Brasileiro de Medicina Veterinária e Zootecnia. 59(2):306-312, 2007.

MURPHY, J.J.; CONNOLLY, J.F.; McNEILL, G.P. Effects on milk fat composition and cow performance of feeding concentrates containing full fat rapessed and maize distillers grains on grasssilage based diets. Livestock Production Science. 44(1):1-11, 1995.

NATIONAL RESEARCH COUNCIL - NRC. Nutrient Requirements of Small Ruminants, Washington, D.C.: National Academy Press. 2007. 362p.

NESTEL, P.J.; POYSER, A.; HOOD, R.L. The effect of dietary fat supplements on cholesterol metabolism in ruminants. Journal of Lipid Research. 19(7):889-909, 1978.

PALMQUIST, D.L.; MATTOS, W.R.S. Metabolismo de lipídeos. In: BERCHIELLI, T.T.; PIRES, A.V.; OLIVEIRA, S.G. et al. Nutrição de Ruminantes. 2.ed. Jaboticabal: Funep, 2011. p.299-322.

PUGH, D.G. Clínica de Ovinos e Caprinos. São Paulo: Roca, 2004. 513p.

RAPETTI, L.; BAVA, L. Feeding Management of Dairy Goats in Intensive Systems. In: CANNAS, A.; PULINA, G. Dairy Goats Feeding and Nutrition. Oxfordshire: CAB International, 2008, p.221-237. 
RODRIGUES, C.A.F; RODRIGUES, M.T.; BRANCO, R.H. Avaliação do consumo e de metabólitos plasmáticos de cabras gestantes com duas condições corporais alimentadas com dietas formuladas com diferentes níveis de energia. Revista Brasileira de Zootecnia. 36(4):945-952, 2007.

SAHLU, T.; HART, S.P.; LE-TRONG, T. Influence of prepartum protein and energy concentrations for dairy goats during pregnancy and early lactation. Journal of Dairy Science. 78(2):378-387, 1995.

SANTOS, F.A.P.; PEDROSO, A.M. Metabolismo de proteínas. In: BERCHIELLI, T.T.; PIRES, A.V.; OLIVEIRA, S.G. Nutrição de Ruminantes. 2.ed. Jaboticabal: Funep, 2011. p.265-297.

SAMPELAYO, S. M.R.; PÉREZ, L.; ALONSO, J.J.M. Effects of concentrates with different contents of protected fat rich in PUFAs on the performance of lactating Granadina goats. 1. Feed intake, nutrient digestibility, $\mathrm{N}$ and energy utilization for milk production. Small Ruminant Research. 43(2):133-139, 2002a.

. Effects of concentrates with different contents of protected fat rich in PUFAs on the performance of lactating Granadina goats. 2. Milk production and composition. Small Ruminant Research. 43(2):141.148, 2002b.

SILVA, D.J.; QUEIROZ, A.C. Análise de Alimentos: Métodos Químicos e Biológicos. 5.ed. Viçosa: Imprensa Universitária, 2002. 235p.
SILVA, M.M.C.; RODRIGUES, M.T.; BRANCO, R.H. Suplementação de lipídios em dietas para cabras em lactação: consumo e eficiência de utilização de nutrientes. Revista Brasileira de Zootecnia. 36(1):257-267, 2007.

SNIFFEN, C.J.; O'CONNOR, J.D.; VAN SOEST, P.J. A net carbohydrate and protein system for evaluating cattle diets: II. Carbohydrate and protein availability. Journal of Animal Science. 70(11):3562, 1992.

VAN SOEST, P.J. et al. Methods for dietary fiber, neutral detergent fiber, and nonstarch polysaccharides in relation to nutrition. In: Symposium carbohydrate methodology metabolism and nutritional implications in dairy cattle. Journal of Dairy Science. 74(10):35833597, 1991.

ZAMBOM, M.A.; ALCALDE, C.R.; MACEDO, F.A.F. Ingestão, digestibilidade das rações e parâmetros sangüíneos em cabras Saanen durante o pré-parto recebendo rações com diferentes níveis de energia, Revista Brasileira de Zootecnia. 35(4):1866-1871, 2006.

ZAMBOM, M.A.; ALCALDE, C.R.; MARTINS, E.N. Curva de lactação e qualidade do leite de cabras Saanen recebendo rações com diferentes relações volumoso :concentrado. Revista Brasileira de Zootecnia. 34(6):2515-2521, 2005a.

ZAMBOM, M.A.; ALCALDE, C.R.; SILVA, K.T. Ingestão, digestibilidade das rações e produção de leite em cabras Saanen submetidas a diferentes relações volumoso:concentrado na ração. Revista Brasileira de Zootecnia. 34(6):02505-2514, 2005 b. 